\title{
Acetylation of $\gamma$-mangostin Isolated from the Mangosteen Pericarp (Garcinia mangostana Linn.) and Their Antidiabetic Activity
}

\author{
Ega Rocky Maulana Rafsanjani, Arif Fadlan and Taslim Ersam \\ Department of Chemistry, Institut Teknologi Sepuluh Nopember, Surabaya \\ e-mail:paktichem@gmail.com
}

\begin{abstract}
Mangosteen (Garcinia mangostana Linn) is one of the most well-known plants in Indonesia. Mangosteen contains many derivatives of oxygenated and prenylated xanthones from phenolics which exhibit diverse biological activities such as antioxidants, antimalarials, anti-allergies, anti-tumors, antiviral, antibacterial, anti-inflammatory, anti-fungal, anticancer, and antidiabetic. Modification of xanthone compounds is known to increase antidiabetic activity and it is known that $\alpha$ - and $\beta$-mangostin acetylated can be produced from the modification of $\alpha$ - and $\beta$-mangostin using acetic anhydride. In this study, as many as 1.43 grams $(1.59 \%)$ of the $\gamma$-mangostin compound were successfully isolated from the ethyl acetate extract of mangosteen pericarp. Modification of $\gamma$ mangostin through the acetylation reaction produces acetylated $\gamma$-mangostin in the form of 3,6,7-tri-methylester- $\gamma$-mangostin as much as $32.9 \mathrm{mg}(63 \%)$. Antidiabetic test results showed $\gamma$ mangostin had an IC50 value of $8.55 \mu \mathrm{M}$, while the IC50 value of 3.6.7-tri-methylester- $\gamma$-mangostin was $1.82 \mu \mathrm{M}$. Acarbose as a positive control has an IC50 value of $4.48 \mu \mathrm{M}$. This shows that modification can increase antidiabetic activity.
\end{abstract}

Keywords-Acetylation, Antidiabetic, Garcinia mangostana Linn.

\section{INTRODUCTION}

$G$ ARCINIA is a genus of plants from the Clusiaceae tribe where no less than 200 species of Garcinia grow spread all over the world [1], [2]. Garcinia specimens stored in the Bogoriense Herbarium and literature studies show that there are 64 species of Garcinia through out Indonesia with the most distribution in the island of Borneo. Garcinia species in Kalimantan are more numerous compared to other islands. As many as 25 species of Garcinia are on the island of Borneo, while in Sumatra and Sulawesi only 22 species each, Maluku and Irian Jaya (Papua) 17 species each, eight Java species, and Nusa Tenggara only five species of Garcinia [3].

Mangosteen (Garcinia mangostana Linn) is reported as a major source and is rich in oxygenated and prenylated xanthones. A total of 50 xanthones compounds that have been successfully isolated from mangosteen pericarp [4]. Some xanthones compounds that have been found in large numbers in mangosteen are $\alpha$-mangostin, $\beta$-mangostin, $\gamma$-mangostin, 3 -isomangostin [5], [6]. One of the xanthones compounds such as $\gamma$-mangostin are xanthones which are reported to have pharmacological effects such as, antioxidants, anticancer, anti-inflammatory, antifungal and antibacterial [4]. In addition, $\gamma$-mangostin has also been reported to have quite good antidiabetic activity with an $\mathrm{IC}_{50}$ value of $4.2 \mu \mathrm{M}$ [7].

Diabetic is a disease caused by the pancreas not being able to produce enough insulin for the body or when the body

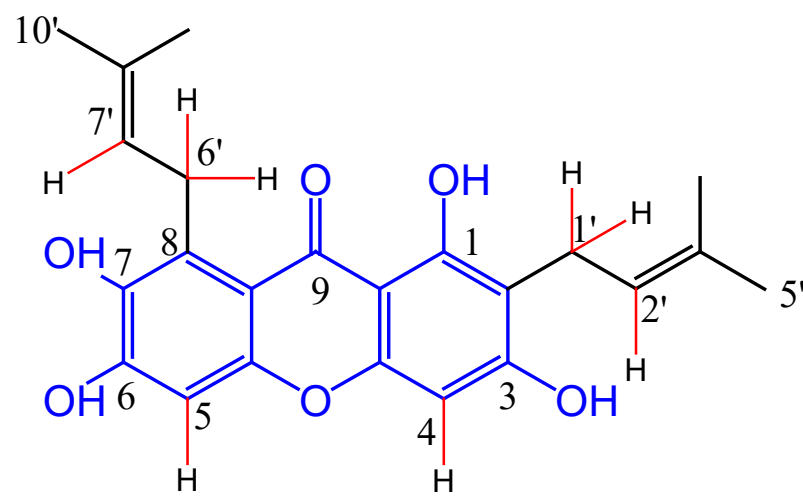

Figure 1. Structure of $\gamma$-mangostin

cannot effectively use the insulin it produces. Insulin is a hormone that regulates blood sugar or glucose in the body [8]. Decreasing the action of insulin will result in changes in carbohydrate, protein and lipid metabolism resulting in an increase in blood sugar levels or called hyperglycemia. Hyperglycemia causes damage to the body's systems, especially blood vessels and nervous system [9], [10]. Diabetes mellitus (DM) is a disease that contributes to the high mortality rate in the world. These complex metabolic diseases are classified into type I and type II DM. Type I DM occurs because the pancreas fails to produce insulin, whereas type II DM refers to the condition of the body's inability to effectively use insulin produced by the body. This causes an increase in glucose levels in the blood or often called hyperglycemia.

Treatment for diabetic patients is taking oral medications (Oral Antidiabetic Drugs - OADs) or herbal medicines derived from nature. Oral medications commonly used for the treatment of diabetes are Metformin, Sulfonylurea and the $\alpha$ glucosidase inhibitor group [11]. Metformin decreases gluconeogenesis in the liver due to insulin sensitivity in the liver [12]. While sulfonylurea works by stimulating insulin secretion [13]. $\alpha$-glucosidase inhibitors work by inhibiting the enzyme $\alpha$-glucosidase which catalyzes the division of disaccharides and oligosaccharides [14]. Oral use of the drug has several side effects in its use. Some side effects include diarrhea, vitamin B12 deficiency, weight gain, hypoglycemia, and nausea in diabetics [14]-[17]. The use of inhibitors as antidiabetic drugs sourced from natural ingredients can be an alternative approach for the treatment of diabetics. These inhibitors have advantages in addition to cheap and affordable prices and also do not have side effects when compared with various types of commercial drugs that have been circulating today [18]. 
The $6^{\text {th }}$ International Seminar on Science and Technology (ISST) 2020

July $25^{\text {th }} 2020$, Institut Teknologi Sepuluh Nopember, Surabaya, Indonesia<smiles>CC(C)=CCc1c(O)cc2oc3cc(O)c(O)c(CC=C(C)C)c3c(=O)c2c1O</smiles><smiles>CC(C)=CCc1c([O-])cc2oc3cc(O)c(O)c(CC=C(C)C)c3c(=O)c2c1O</smiles><smiles>[R]Oc1cc2oc3cc(OC(C)=O)c(CC=C(C)C)c(O)c3c(=O)c2c(CC=C(C)C)c1[R20]</smiles><smiles>CC(=O)O[AlH2]</smiles><smiles>C=C(OC(C)=O)C(C)OC(C)=O</smiles>

Figure 2. Proposed Mechanism of the Acetylation Reaction

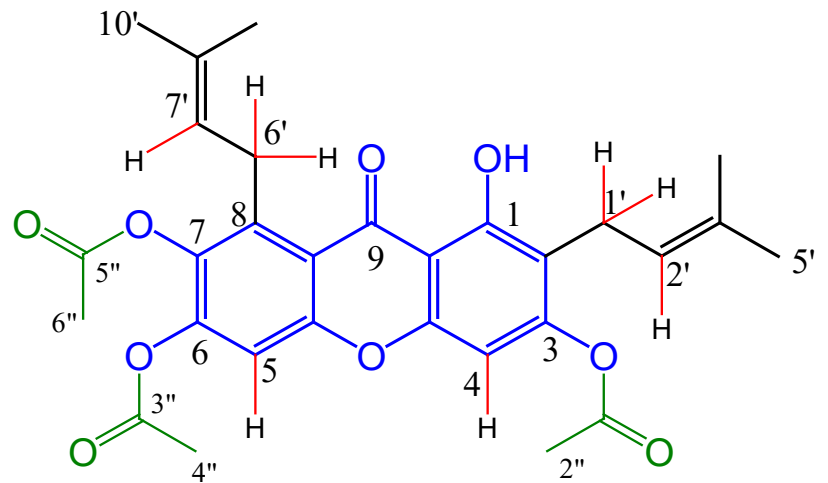

Figure 3. Actualization of the ${ }^{13} \mathrm{C}-\mathrm{NMR}$ Spectrum of Compounds (2)

Research on isolation of xanthone compounds has been done, but not many researchers have modified xanthone compounds to get new xanthones derivatives. One technique for modification of xanthone compounds is acetylation. Acetylation is the process of adding an acetyl group to the structure of the desired compound. Alcohol and phenol protection is one of the most commonly used synthetic strategies to mask hydroxyl functions during multistep synthetic procedures. In addition, O-acetylation procedure is widely used to obtain derivatives of new compounds that can increase biological activity [19]. Modification of the $\alpha$ mangostin compound to 3,6-di- $O$-acetyl- $\alpha$-mangostin using anhydrous acetate as an acetylation agent has been successfully carried out [20]. The addition of the acetyl group in the xanthone structure will certainly affect the results of the ${ }^{13} \mathrm{C}$-NMR test. The increase in number $\left(\delta_{\mathrm{c}}\right)$ naturally depends on the number of acetyl substituents substituted in xanthones.
3,6-di-O-acetyl- $\alpha$-mangostin spectrum as a result of acetylation of the $\alpha$-mangostin compound showed the existence of four new $\left(\delta_{\mathrm{c}}\right)$ at $167.9 \mathrm{ppm} ; 168.4 \mathrm{ppm}(-\mathrm{CO})$ and 20.9 ppm; $21 \mathrm{ppm}(\mathrm{CH} 3)$. In the acetylation of the compound cochinchinone A to 3,7-di-O-acetylcochinchinone A also showed the addition of four $(\delta \mathrm{c})$, which is two at $168.3 \mathrm{ppm}$; $169.2 \mathrm{ppm}(-\mathrm{CO})$, and two at $20.6 \mathrm{ppm} ; 21 \mathrm{ppm}$ is $(\delta \mathrm{c})$ of methyl [20].

The acetylation of 1,3-dihydroxycantone to 1,3diacetoxysantone compounds can increase the inhibitory activity of the $\alpha$-glucosidase enzyme from $160.8 \mu \mathrm{M}$ to 31.9 $\mu \mathrm{M}$ [21]. $\alpha$-glucosidase is an enzyme in digestion which breaks down carbohydrates from oligo- or poly-saccharide forms into monosaccharides including glucose, galactose and fructose [18]. Inhibition of the $\alpha$-glucosidase enzyme will inhibit glucose absorption so that glucose levels in the blood do not increase. Thus, $\alpha$-glucosidase inhibitors can be used as antidiabetic [22].

\section{METHODOLOGY}

\section{A. Instrument}

Equipment used in this study includes glassware, a set of chromatography tools, analytical balance, Cimarec hot plate SP131320-33 (Cimarec, China), 60 GF254 silica gel TLC plates (Merck kGaA 64271, Darmstadt, Germany), Fisher John melting point apparatus (Phillips Haris, USA), vortex mixer, rotary vacuum evaporator Buchi R-210 (Buchi, Switzerland), Genesys 10S UV-Vis spectrophotometer (Thermofisher, USA) Shimadzu 8400S Fourier transforminfrared (Shimadzu, Kyoto, Japan), NMR spectrometer 
The $6^{\text {th }}$ International Seminar on Science and Technology (ISST) 2020

July $25^{\text {th }} 2020$, Institut Teknologi Sepuluh Nopember, Surabaya, Indonesia

Table 2.

Comparison of 13C-NMR $\gamma$-mangostin and Compounds (2).

\begin{tabular}{|c|c|c|c|c|c|}
\hline posisi C- & $\underset{(\mathrm{ppm})}{\gamma-\operatorname{mangostin} \delta \mathrm{C}}$ & $\begin{array}{c}\text { Compounds (2) } \delta \mathrm{C} \\
(\mathrm{ppm})\end{array}$ & posisi C- & $\underset{(\mathrm{ppm})}{\gamma-\underset{\text { mangostin }}{\mathrm{m}} \delta \mathrm{C}}$ & $\begin{array}{c}\text { Compounds (2) } \delta \mathrm{C} \\
(\mathrm{ppm})\end{array}$ \\
\hline 1 & 161,7 & 156,2 & $3^{\prime}$ & 131,3 & 132,6 \\
\hline 2 & 110,8 & 111,8 & $4^{\prime}$ & 17,9 & 17,9 \\
\hline 3 & 155,7 & 154,6 & $5^{\prime}$ & 26,1 & 25,9 \\
\hline 4 & 92,9 & 101,7 & $6^{\prime}$ & 26,4 & 27,2 \\
\hline $4 a$ & 162,7 & 156,4 & $7^{\prime}$ & 124,5 & 122,2 \\
\hline $4 \mathrm{~b}$ & 152,3 & 138,9 & $8^{\prime}$ & 131,3 & 132,5 \\
\hline 5 & 101,1 & 101,8 & $9^{\prime}$ & 18,3 & 18,3 \\
\hline 6 & 153,5 & 149,1 & $10^{\prime}$ & 25,9 & 25,8 \\
\hline 7 & 141,6 & 138,5 & $1 "$ & & 168,9 \\
\hline 8 & 129,1 & 122,5 & $2^{\prime \prime}$ & & 20,9 \\
\hline $8 \mathrm{a}$ & 112,0 & 116,8 & $3 "$ & & 161,5 \\
\hline $9 \mathrm{a}$ & 103,7 & 107,6 & $4 "$ & & 20,3 \\
\hline 9 & 183,2 & 183,9 & $5^{\prime \prime}$ & & 167,9 \\
\hline $1^{\prime}$ & 22,0 & 22,8 & $6 "$ & & 20,7 \\
\hline $2^{\prime}$ & 123,5 & 117,2 & & & \\
\hline
\end{tabular}

DELTA2_JEOL ECS (JEOL, Japan), HR-ESI-MS LTQ Orbitrap (ThermoFinnigan, Bremen, Germany).

\section{B. Material}

The material used in this study was a sample of $G$. mangostana mangosteen pericarp from Pujer District, Bondowoso. Technical organic solvents include n-hexane, dichloromethane, ethylacetate, methanol, and distilled water. Silica gel $60 \mathrm{G}$, (Merck-1.07731.1000) and silica gel 60 0,063-0,200 mm (Merck-1.07734.1000) for vacuum liquid chromatography and column chromatography, TLC plate/silica gel $60 \mathrm{~F}_{245}$ aluminum sheets $20 \mathrm{x} 20 \mathrm{~cm}$ (Merck 4.05554.0001), filter paper, aluminum foil, stain-looking reagents $\left(1.5 \%\right.$ solution of $\mathrm{CeSO}_{4}$ in $\left.\mathrm{H}_{2} \mathrm{SO}_{4}\right)$ on the TLC plate.

The ingredients used to modify $\gamma$-mangostin and antidiabet activity test in this study were samples of $\gamma$-mangostin compound, acetic anhydride, sodium acetate, proteleum ether, acetone, chloroform, aquades, phosphate buffer (pH6,9), glucose kit, sucrose $100 \mu \mathrm{M}$, DMSO.

\section{Isolation of $\gamma$-mangostin}

The $\gamma$-mangostin isolate was obtained from the maceration process of dried mangosteen pericarp using ethyl acetate solvent. The extract obtained was then evaporated using a rotary evaporator at low pressure so that the solvent was extracted. Concentrated ethyl acetate extract obtained was fractionated using silica gel chromatography column. The profiles of pure compounds in a fraction are marked by a single stain on the TLC plate. The compound is confirmed to be pure and through the process of structural identification using UV, IR, MS and NMR instruments.

\section{Acetylation}

Acetylation of $\gamma$-mangostin is carried out through the acetylation reaction with the sodium acetate catalyst [21]. $\gamma$ mangostin (39.6 mg, $1 \mathrm{mmol}$ ) was dissolved in anhydrous acetate $(2.5 \mathrm{~mL})$. Subsequently, sodium acetate $(103 \mathrm{mg}$,
$0.125 \mathrm{mmol})$ was added to the solution and the reaction mixture was stirred at $60^{\circ} \mathrm{C}$ (TLC monitoring). After the reaction is complete, the solvent is evaporated using a rotary evaporator and the residue obtained is partitioned using distilled water: chloroform (1:1). The organic layer was separated, the solvent was evaporated at low pressure, and TLC was tested with eluent proteleum ether: acetone (7: 3). Acetylation products obtained were identified by the ${ }^{13} \mathrm{C}$ NMR spectroscopic method.

\section{E. Antidiabetic test}

Antidiabetic activity tests were carried out using the $\alpha$ glucosidase enzyme inhibition method [23]. Samples of 10 $\mu \mathrm{L}, 0.1 \mathrm{M}$ phosphate buffer (pH 6.9) $30 \mu \mathrm{L}, 100 \mu \mathrm{M}$ sucrose $20 \mu \mathrm{L}$, glucose kit $80 \mu \mathrm{L}$, and $20 \mu \mathrm{L}$ enzyme supernatant were incubated at $37^{\circ} \mathrm{C}$ for 10 minutes. Akarbosa is used as a positive control. Absorbance was recorded at a wavelength of $490 \mathrm{~nm}$ on a UV-Vis spectrophotometer. Inhibitory activity is determined from the following equation:

Inhibition $(\%)=\left[\frac{\text { Abs.blank-Abs.sample }}{\text { Abs.blank }}\right] \times 100$

The $\alpha$-glucosidase enzyme inhibition test was performed on various dilution samples to look for logarithmic regression equations so that $\mathrm{IC}_{50}$ values of the samples could be determined.

\section{RESULTS AND DISCUSSION}

\section{A. Isolation $\gamma$-mangostin}

The isolation process begins with the maceration process of dried mangosteen pericarp powder using ethyl acetate. Maserat obtained from maceration results as much as $15 \mathrm{~L}$, then concentrated with a rotary evaporator. The first maceration process gave 374.14 ethyl acetate extract, while the second and third maceration produced 121.05 extracts, and 39.82 grams. Ethyl acetate extract $(90 \mathrm{~g})$ was fractionated using a Vacuum Liquid Chromatography (VLC) column with 
The $6^{\text {th }}$ International Seminar on Science and Technology (ISST) 2020

July $25^{\text {th }} 2020$, Institut Teknologi Sepuluh Nopember, Surabaya, Indonesia

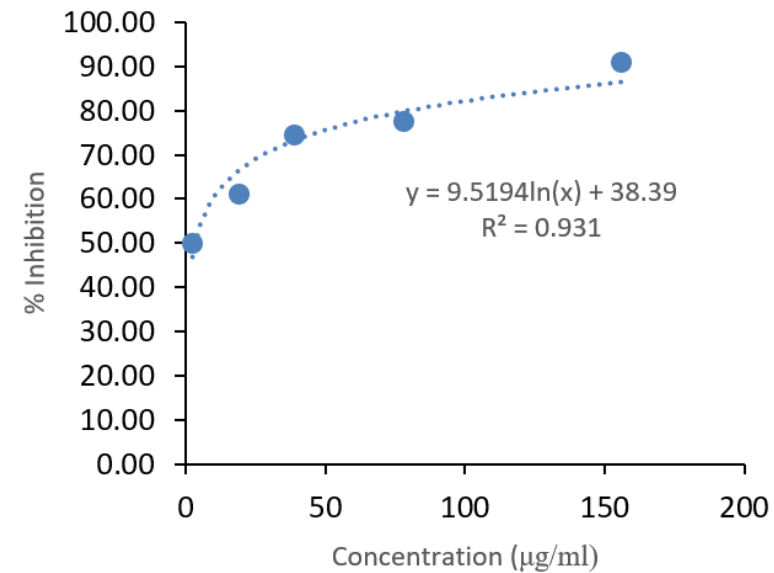

(1)

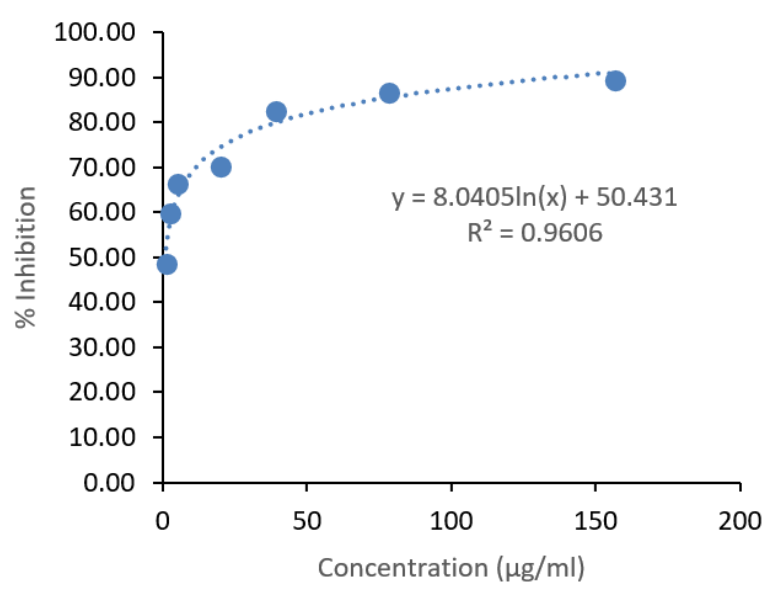

(2)

Figure 4 Regression curve of (1) $\gamma$-mangostin, and (2) 3,6,7-tri-methylester- $\gamma$-mangostin

$60 \mathrm{G}(250 \mathrm{~g})$ silica gel and n-hexane-EtOAc (Increasing Polarity) eluent gradient until a single stain profile was obtained. After that the solvent fraction is evaporated solvent at low pressure. The solids formed were then recrystallized, tested for purity, and the identification of the structure obtained compounds (1) $\gamma$-mangostin as in Figure 1 totaling $1.43 \mathrm{~g}$.

\section{B. Acetylation}

The $\gamma$-mangostin compound that was successfully obtained from the ethyl acetate extract of G. mangostana pericarp was modified by the acetylation method. $0.1 \mathrm{mmol}$ of $\gamma$-mangostin compound was dissolved in $2.5 \mathrm{ml}$ of anhydrous acetate. Next, add sodium acetate catalyst 0.25 mmol.

The reaction mixture is stirred at $60^{\circ} \mathrm{C}$ and the running reaction is monitored by TLC. Monitoring of the acetylation reaction using TLC showed that the reaction in the $60^{\text {th }}$ minute had gone perfectly marked by the absence of a reactant stain or $\gamma$-mangostin (the reactor had finished reacting). Based on this, the acetylation reaction is then stopped. Then the reaction mixture is partitioned using aquades-chloroform (1:1). The organic phase obtained is then evaporated at a low pressure temperature.

The formed crystals are washed using aquades to remove impurities. The crystal was tested for purity using TLC with three different eluents. The purity test results show that the reaction crystals are pure compounds that are characterized by the presence of a single stain on each plate and there are no impurities at the top or at the bottom of the stain. The pure compound resulting from the acetylation reaction is referred to as compound (2). The compound (2) produced from the acetylation reaction was $32.9 \mathrm{mg}(63 \%)$.

Structural identification was carried out using ${ }^{13} \mathrm{C}-\mathrm{NMR}$ spectroscopy. The obtained spectrum results were compared with the ${ }^{13} \mathrm{C}$-NMR $\gamma$-mangostin spectrum. The entry of the acetyl group will certainly affect the number of carbon peaks in the 13C NMR spectrum of compound (3). Acetylation of xanthones at $60^{\circ} \mathrm{C}$ can substitute free hydroxy groups in xanthones [21]. $\gamma$-mangostin contains three free hydroxyl groups in xanthone structure, then it is possible that the three hydroxyl groups are acetylated.
Based on the ${ }^{13} \mathrm{C}$-NMR spectrum of compound (2), the addition of 3 methyl signals and 3 carbonyl signals indicates that 3 acetyl groups have successfully entered the xanthone structure by substituting three free hydroxy groups. The following is a comparison table of ${ }^{13} \mathrm{C}$-NMR $\gamma$-mangostin and compound (2).

Based on the results of the ${ }^{13} \mathrm{C}-\mathrm{NMR}$ analysis of compound (2) and its comparison with the ${ }^{13} \mathrm{C}$-NMR spectrum of $\gamma$ mangostin, it can be concluded that the compound formed from the acetylation reaction is 3,6,7-tri-methylester- $\gamma$ mangostin (Figure 3).

\section{Antidiabetic Test}

Antidiabetic test through the mechanism of $\alpha$-glucosidase inhibition in various dilution samples is done to find the logarithmic regression equation so that the $\mathrm{IC}_{50}$ value of the sample can be determined. IC50 is the concentration of a compound needed to inhibit the activity of the $\alpha$-glucosidase enzyme by $50 \%$. $\alpha$-glucosidase is an enzyme in digestion which breaks down carbohydrates from oligo- or polysaccharide forms into monosaccharides including glucose, galactose and fructose [18]. Inhibition of the $\alpha$-glucosidase enzyme will inhibit glucose absorption so that glucose levels in the blood will not continue to increase. Thus, $\alpha$-glucosidase inhibitors can be used as antidiabetic [22].

The logaritmic regression equation $\gamma$-mangostin and 3,6,7tri-methylester- $\gamma$-mangostin show that $\mathrm{IC}_{50}$ value 3,6,7-trimethylester- $\gamma$-mangostin which is $1.82 \mu \mathrm{M}$ higher than $\gamma$ Mangostin which gave $\mathrm{IC}_{50} 8.55 \mu \mathrm{M}$ and higher than the acarbose as a positive control which gave $\mathrm{IC}_{50}$ value $4.48 \mu \mathrm{M}$. This concludes that the $\gamma$-mangostin acetylation process to 3,6,7-tri-methylester- $\gamma$-mangostin is able to increase antidiabetic activity. This is consistent with the study which showed an increase in the $\mathrm{IC}_{50}$ value of 1,3-dihydroxysantone compounds by $160.8 \mu \mathrm{M}$ to $31.9 \mu \mathrm{M}$ in 1,3-diacetoxysantone compounds [21] [21].

\section{CONCLUSION}

Isolation of the $\gamma$-mangostin compound from the mangosteen pericarp G. mangostana was successfully carried out. Acetylation of $\gamma$-mangostin compound to 3,6,7-tri- 
The $6^{\text {th }}$ International Seminar on Science and Technology (ISST) 2020

July $25^{\text {th }} 2020$, Institut Teknologi Sepuluh Nopember, Surabaya, Indonesia

methylester- $\gamma$-mangostin is known to be able to increase antidibetes activity. $\mathrm{IC}_{50}$ value of compound 3,6,7-trimethylester- $\gamma$-mangostin is higher than $\gamma$-mangostin compound and higher than acarbose as a positive.

\section{REFERENCES}

[1] P. C. M. Jansen, J. Jukema, L. P. A. Oyen, and T. G. van Lingen, "Minor Edible Fruits and Nuts," in Edible Fruits and Nuts, E. W. M. Verheij and R. F. Coronel, Eds. Bogor, Indonesia: Plants Resources of South-East Asia (PROSEA), 1991, pp. 175-177.

[2] N. Noor, "Garcinia celebica," in Timber Trees: Lesser-Known Timber, Bogor, Indonesia: Plants Resources of South-East Asia (PROSEA), 1998, pp. 246-249.

[3] T. Uji, "Keanekaragaman, persebaran, dan potensi jenis-jenis Garnicia di Indonesia," Berk. Penelit. Hayati, vol. 12, no. 2, pp. 129-135, 2007.

[4] J. Pedraza-Chaverri, N. Cárdenas-Rodríguez, M. Orozco-Ibarra, and J. M. Pérez-Rojas, "Medicinal properties of mangosteen (Garcinia mangostana)," Food Chem. Toxicol., vol. 46, no. 10, pp 3227-3239, 2008, doi: 10.1016/j.fct.2008.07.024.

[5] A. P. Sari, "Senyawa $\alpha$ dan $\gamma$-mangostin dari Kulit Buah Garcinia mangostana L," Institut Teknologi Sepuluh Nopember, 2011.

[6] S. Fatmawati, T. Ersam, and K. Shimizu, "The inhibitory activity of aldose reductase in vitro by constituents of Garcinia mangostana Linn," Phytomedicine, vol. 22, no. 1, pp. 49-51, 2015, doi: 10.1016/j.phymed.2014.11.001.

[7] B. Vongsak, S. Kongkiatpaiboon, S. Jaisamut, S. Machana, and C. Pattarapanich, "In vitro alpha glucosidase inhibition and freeradical scavenging activity of propolis from Thai stingless bees in mangosteen orchard," Rev. Bras. Farmacogn., vol. 25, no. 5, pp. 445-450, 2015, doi: 10.1016/j.bjp.2015.07.004.

[8] World Health Organization, "Global report on diabetes," 2016. http://www.who.int/diabetes/global-report/en/.

[9] American Diabetes Association, "Diagnosis and classification of diabetes mellitus," Diabetes Care, vol. 37, no. SUPPL.1, pp. S81S90, 2014, doi: $10.2337 / \mathrm{dc} 14-\mathrm{S} 081$.

[10] World Health Organization (WHO), Definition, Diagnosis, and Classification of Diabetes Mellitus and Its Complications. Geneva, Switzerland: WHO Press, 1999.

[11] S. Surya, A. D. Salam, D. V. Tomy, B. Carla, R. A. Kumar, and C. Sunil, "Diabetes mellitus and medicinal plants-a review," Asian Pacific J. Trop. Dis., vol. 4, no. 5, pp. 337-347, 2014, doi: $10.1016 / \mathrm{S} 2222-1808(14) 60585-5$.

[12] G. Zhou et al., "Role of AMP-activated protein kinase in mechanism of metformin action," J. Clin. Invest., vol. 108, no. 8 , pp. 1167-1174, 2001, doi: 10.1172/JCI13505.

[13] R. R. Holman, "Long-term efficacy of sulfonylureas: a United Kingdom Prospective Diabetes Study perspective," Metabolism., vol. 55, no. SUPPL. 1, pp. S2-S5, 2006, doi 10.1016/j.metabol.2006.02.006.

[14] S. K. Morcos and H. S. Thomsen, "European Society of Urogenital Radiology guidelines on administering contrast media," Abdom. Imaging, vol. 28, no. 2, pp. 187-190, 2003, doi: 10.1007/s00261001-0186-5.

[15] L. Jackson and L. Robertson, "Sulphonylureas (specifically glibenclamide) and their correct dosage," South African Med. J., vol. 76 , no. $6,1989$.

[16] G. I. Varughese, A. A. Tahrani, and J. H. B. Scarpello, "The long and short of metformin-related vitamin B12 deficiency," Arch. Intern. Med., vol. 167, no. 7, pp. 729-730, 2007, doi 10.1001/archinte.167.7.729-b.

[17] R. Z. W. Ting, C. C. Szeto, M. H. M. Chan, K. K. Ma, and K. M. Chow, "Risk factors of vitamin B12 deficiency in patients receiving metformin," Arch. Intern. Med., vol. 166, no. 18, pp. 1975-1979, 2006, doi: 10.1001/archinte.166.18.1975.

[18] K. Y. Kim, K. A. Nam, H. Kurihara, and S. M. Kim, "Potent $\alpha-$ glucosidase inhibitors purified from the red alga Grateloupia elliptica," Phytochemistry, vol. 69, no. 16, pp. 2820-2825, 2008, doi: 10.1016/j.phytochem.2008.09.007

[19] M. M. Mojtahedi and S. Samadian, "Efficient and rapid solventfree acetylation of alcohols, phenols, and thiols using catalytic amounts of sodium acetate trihydrate," J. Chem., vol. 2013, 2013 , doi: $10.1155 / 2013 / 642479$

[20] Y. Ren et al., "Cytotoxic and NF-אB inhibitory constituents of the stems of Cratoxylum cochinchinense and their semisynthetic analogues," J. Nat. Prod., vol. 74, no. 5, pp. 1117-1125, 2011, doi: 10.1021/np200051j.

[21] Y. Liu, L. Zou, L. Ma, W. H. Chen, B. Wang, and Z. Le Xu, "Synthesis and pharmacological activities of xanthone derivatives as $\alpha$-glucosidase inhibitors," Bioorganic Med. Chem., vol. 14, no. 16, pp. 5683-5690, 2006, doi: 10.1016/j.bmc.2006.04.014

[22] S. Fatmawati, K. Shimizu, and R. Kondo, "Ganoderol B: A potent $\alpha$-glucosidase inhibitor isolated from the fruiting body of Ganoderma lucidum," Phytomedicine, vol. 18, no. 12, pp. 10531055, 2011, doi: 10.1016/j.phymed.2011.03.011.

[23] S. R. Ayinampudi, R. Domala, R. Merugu, S. Bathula, and M. R. Janaswamy, "New icetexane diterpenes with intestinal $\alpha$ glucosidase inhibitory and free-radical scavenging activity isolated from Premna tomentosa roots," Fitoterapia, vol. 83, no. 1, pp. 8892, 2012, doi: 10.1016/j.fitote.2011.09.018. 